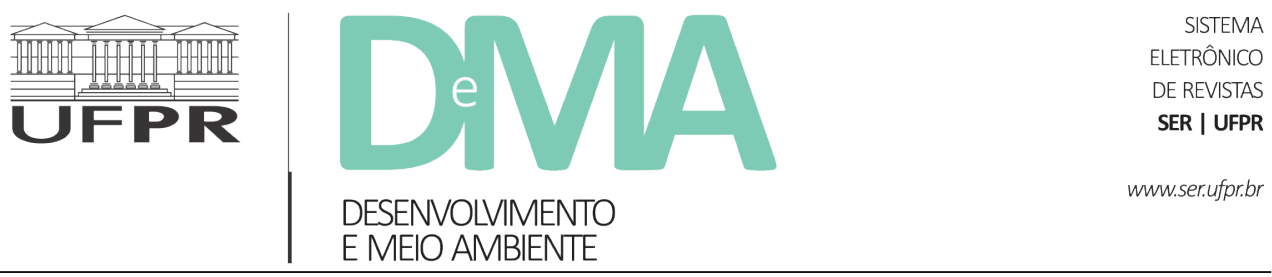

\title{
The Chico Mendes Extractive Reserve: trajectories of agro- extractive development in Amazonia
}

\section{A Reserva Extrativista Chico Mendes: trajetórias do desenvolvimento agroextrativista na Amazônia}

\author{
Richard H. WALLACE ${ }^{*}$, Carlos Valério A. GOMES ${ }^{2}$, Natalie A. COOPER ${ }^{3}$ \\ ${ }^{1}$ Department of Anthropology, Geography and Ethnic Studies, California State University, Stanislaus, Turlock, CA, USA. \\ ${ }^{2}$ Instituto Amazônico de Agriculturas Familiares, Universidade Federal de Pará (UFPA), Belém, PA, Brazil. \\ ${ }^{3}$ School of Forest Resources and Conservation and Tropical Conservation and Development Program, Center for Latin American Studies, \\ University of Florida, Gainesville, FL, USA.
}

*E-mail of contact: rwallace@csustan.edu

Article received in April 10, 2018, final version accepted in August 30, 2018.

ABSTRACT: The Chico Mendes Extractive Reserve (CMER) located in Acre, Brazil in the southwest Amazon is a powerful symbol of the rubber tapper social movement. Created in 1990, the Reserve is named after rubber tapper and union leader Francisco "Chico" Mendes, who was assassinated by ranchers in 1988. The concept of the extractive reserve, a type of sustainable-use protected area, was conceived by rubber tappers to secure land rights and to protect the forests from which they derived their livelihoods. Thirty years since its creation, non-timber forest product (NTFP) extraction maintains a critical role in CMER resident livelihoods, but it is now one of multiple and dynamic trajectories of income generating activities in the CMER. The state government has promoted sustainable development policies aimed at productive and multiple use of forests, including community-based timber management (CBTM). Concomitantly, the scale and scope of small-scale cattle ranching reflecting a growing "cowboy culture" pervasive in Eastern Acre is growing. These forces have brought sociocultural changes to the reserve as CMER residents engage these intertwined trajectories to improve their livelihoods. This article explores the trajectories of multiple development strategies in the CMER. We do this by revisiting and expanding on the principal themes of research of the co-authors - NTFP extraction, cattle ranching, and CBTM. Increasingly diverse CMER households demand multiple pathways to improve livelihoods, and these trajectories have created new economic opportunities for reserve residents. Although the NTFP sector has experienced some success 
in market development and valued-added initiatives, investments have not produced a sustainable and diversified extractive sector. Cattle ranching and CBTM have provided economic benefits to reserve residents' livelihoods, but they have also created internal tensions across the social movement and governments agencies. A strategic vision is required that brings diverse government, non-government and reserve residents together and articulates how these dynamic, linked, and sometimes conflicting trajectories can synergize within a balanced, diversified livelihood framework to ensure long-term sustainability of the CMER.

Keywords: Amazon; extractive reserve; sustainable development; Chico Mendes.

RESUMO: $\quad$ A Reserva Extrativista Chico Mendes (RECM) localizada no Acre, Brasil, no sudoeste amazônico é um importante símbolo do movimento social dos seringueiros. Criada em 1990, a Reserva recebeu o nome do seringueiro e líder sindical Francisco "Chico" Mendes, assassinado por fazendeiros em 1988. O conceito de Reserva Extrativista, um modelo de área protegida de uso sustentável, foi concebido por seringueiros para garantir o direito à terra e proteger as florestas das quais derivam seus meios de vida extrativista. Trinta anos após sua criação, a extração de produtos florestais não madeireiros (PFNM) mantém um papel importante nos modos de produção dos residentes, mas agora como uma das múltiplas e dinâmicas trajetórias de atividades de geração de renda na RECM. O governo do estado tem promovido políticas de desenvolvimento sustentável destinadas ao uso produtivo e múltiplo das florestas, incluindo o manejo florestal comunitário madeireiro (MFCM). Concomitantemente, o escopo da atividade de pecuária de pequena escala, refletindo uma crescente cultura de "cowboy", tem penetrado e aumentado no sudeste acriano. Essas forças vêm trazendo mudanças socioculturais para a reserva, à medida que os residentes da CMER se engajam nessas interligadas trajetórias para melhorar seus modos de vida. Este artigo explora as trajetórias de múltiplas estratégias de desenvolvimento na RECM. Fazemos isso revisitando e expandindo os principais temas de pesquisa dos coautores - extração de PFNM, pecuária e MFCM. A crescente diversidade das famílias na RECM demanda múltiplos caminhos para melhorar os modos de vida, e essas trajetórias criaram novas oportunidades econômicas para os residentes da reserva. Embora o setor de PFNMs tenha experimentado algum sucesso em iniciativas de desenvolvimento de mercado e de valor agregado, os investimentos não produziram um setor extrativista sustentável e diversificado. A criação de gado e o MFCM tenham beneficiado economicamente os meios de vida dos residentes de reserva, porém eles também criaram tensões internas no movimento social e nas agências governamentais. É necessária uma visão estratégica que reúna governos, instituições não governamentais e residentes da reserva e articule como essas trajetórias dinâmicas, interligadas, e às vezes conflitantes podem se sinergizar para garantir a sustentabilidade de longo prazo da RECM.

Palavras-chave: Amazônia; reserva extrativista; desenvolvimento sustentável; Chico Mendes.

\section{Introduction}

The Chico Mendes Extractive Reserve (CMER) located in Acre, Brazil in the Southwest Amazon is a powerful symbol of the rubber tapper social movement. Created in 1990, the reserve is named after rubber tapper and union leader Francisco "Chico" Mendes, who was assassinated by ranchers in 1988. The CMER represents the history of more than a century of the rubber tappers' struggle to persist in highly exploitative and even abusive relationships with patrons (Bunker, 1984), as well as their achievements through social organization and resistance to well-armed and politically connected ranchers to secure land tenure and livelihood security (Schmink, 1992; Allegretti, 2008). 
An extractive reserve, a type of sustainable use protected area conceptualized by rubber tappers and their allies (Allegretti, 1990) provides land tenure rights while simultaneously protecting the existing social, economic and cultural livelihoods of forest-based communities and conserving forest cover (Allegretti, 1990; Fearnside, 1989). ${ }^{1}$ Socio-economic livelihoods in the CMER have been largely characterized by forest extractivism, or the extraction, processing, and in some cases sales of non-timber forest products (NTFPs) - principally rubber (Hevea brasiliensis) and Brazil nuts (Bertholettia excelsa) - as well as other forest-derived resources like fruits, oils, resins, medicinal plants and animals.

Apart from land tenure, resource utilization regulations at the community level were a principal concern in the early stages of the creation of the CMER. The newly created National Center for the Sustainable Development of Traditional Populations (CNPT) of the Brazilian Environmental Protection Agency (IBAMA) was made the government institution responsible for extractive reserves. This step was followed by the development of extractive reserve utilization plans, jointly created by rubber tapper associations and government representatives, where federal environmental legislation and traditional rubber tapper resource utilization were reconciled (IBAMA, 1995). The CMER Utilization Plan (IBAMA, 1995) ensured that reserve residents would hold long term tenure and use rights to large individual landholdings (colocações), the primary goal of their struggle (Allegretti, 1994). The plan's heavy emphasis on NTFP extraction, with rules imposing a limit on agricultural activities and prohibiting commercial timber extraction, communicated a distinct vision promoting residents' well-being through forest extractivism.

Thirty years after the death of Chico Mendes and the establishment of the CMER, much has changed in terms of livelihood strategies and development initiatives. Although a focus on NTFP extraction continues, it is one of multiple and intertwined socio-economic activities practiced by CMER residents (Wallace, 2004; 2009; Gomes, 2009; Gomes et al., 2012a; Cooper \& Kainer, 2018). These changes have been largely driven by forces external to the CMER: policies promoted by the Acre state Workers' Party (PT) self-named "Forest Government" that was elected in 1999, as well as widespread sociocultural changes in the state and household decisions to engage diversification. The Forest Government strengthened the extractive sector across the state through polices that supported multiple productive uses of forest resources, including community-based timber management (Kainer et al., 2003; Wallace \& Gomes, 2016), thus broadening the concept of sustainable forest extraction. At the same time, cattle ranching driven by socio-economic changes (Gomes, 2009; Gomes et al., 2012b), and an imported "cowboy culture" (Hoelle, 2015), linked to regional ranching market forces (Nepstad et al., 2006; Smeraldi \& May, 2008; Walker et al., 2009; Pacheco \& Poccard-Chapuis, 2012), have influenced small-scale cattle ranching practices among extractivist communities, including in the CMER. Together, these forces have driven a more diverse livelihood portfolio in the reserve.

\footnotetext{
${ }^{1}$ Extractive reserves fall under the International Union for Conservation of Nature (IUCN) Category IV protected area classification (protected area with sustainable use of natural resources). Available at: https://www.iucn.org/theme/protected-areas/about/protected-areas-categories/ category-vi-protected-area-sustainable-use-natural-resources.
} 
Although the extraction of NTFPs continues to thrive as a livelihood strategy in many households in the CMER, and Acre state policies and investments in regional extractive industries have helped rubber tappers earn higher prices for rubber and Brazil nuts, the expansion of cattle production and regional CBTM initiatives have reframed the scope of CMER livelihoods (Stone, 2003; Gomes et al., 2012b). These distinct yet intertwined and dynamic trajectories - extraction, cattle, and timber management - have directly and visibly affected reserve land-use/cover change (Vadjunec et al., 2009), and caused tension within and among diverse reserve stakeholder groups, including between rubber tapper neighbors. These tensions, or dilemmas (Ehringhaus, 2005) have led to new debates over the future of the reserve and its inhabitants.

In this article we explore these three trajectories of socio-economic development in the CMER. We do this by revisiting and expanding on the principal themes of research of the three authors - NTFP extraction, cattle ranching practices, and CBTM - dating back to 1996, while incorporating other relevant studies conducted in the CMER that address these three themes. We also consider key Acre state government policies that have led to the expansion and diversification of economic activities in the reserve. In discussing timber management, we provide an overview of CBTM to contextualize this still emerging development strategy in the CMER. Although we focus on these three trajectories, we recognize the importance of other income earning production activities undertaken by reserve households, including agriculture, such as the production and sale of manioc flour (farinha) off-farm labor, and household participation in exploratory programs involving payments for environmental services (PES). However, we concentrate on what we believe, based on our combined decades of research in the reserve, are the main foci of debate among CMER stakeholders, including reserve residents, social organizations, and regional policy makers. These three income-earning activities are also intimately tied to regional land use and forest conservation. We also note that these trajectories are intertwined and dynamic: for instance, income from extractive activities, particularly Brazil nut sales, can fuel investments in cattle production. Thus, although we break out these trajectories and discuss them separately, they are interrelated and often complementary - and sometimes conflicting - productive activities.

We suggest that although state policies and investments have strengthened and helped add value to NTFPs, the strong push by the Acre state government to incorporate timber management into sustainable development planning, combined with a growing Acre ranching culture that has seeped into the CMER, has led to a more complex picture of forest-based livelihoods today than those envisioned by Chico Mendes and the rubber tapper social movement when the extractive reserve concept was designed. Although these productive strategies have produced economic benefits for CMER households, accumulated research and experience suggest there are significant technical, management, and governance challenges of implementing, administering and monitoring productive land use activities within the vast, nearly one million hectares area of the CMER. Further, attention to social tensions across and among diverse CMER stakeholders, both within and outside the reserve, will be an important prerequisite to better understand how diversification strategies such as CBTM and cattle ranching, and 
more novel approaches like PES, can help stakeholders coalesce around a sustainable vision of future livelihoods in the CMER.

\section{The Chico Mendes Extractive Reserve: utilization plan and extractive priorities}

The CMER is the largest of five federal extractive reserves in Acre and the second largest in Brazil. It is located in what is known as the Upper Acre region, and extends across six municipalities, with the cities of Xapuri, Brasiléia and Assis Brasil serving as the main jumping off points into the reserve. The reserve is divided into 46 rubber estates (seringais), or forest areas, based on lands held and delineated by rubber barons (seringalistas) dating to the late 1800 s and early 1900s. The division of forest areas now serves as a basis for community/ political organization within the reserve.

Natural resource management in the CMER is rooted in Presidential Decree No. 98.897 dated January 30, 1990 that established the extractive reserve concept. The Presidential Decree states clearly that these federal areas, to be administered by the CNPT/IBAMA (now administered by the Chico Mendes Institute for Biodiversity Conservation (ICMBio)), are for "sustainable exploration and conservation of renewable natural resources by extractive populations" and that exploration should be "without loss to environmental conservation" (IBAMA 1995, p. 12). The plan makes this clear through its nuanced focus on extraction - both for use and commercialization. It makes explicit reference to rubber tapper responsibilities to maintain rubber and Brazil nut trails, specifies the types of cuts to be used on rubber trees to collect latex, forbids the cutting down of rubber or Brazil nut trees, permits the continued use of other extractive products and animals for building materials and consumption, and suggests the ability to commercialize other extractive plant-based products once research documents the sustainability of these activities, and management plans are developed. The plan's prohibition of non-domestic use of timber (including subsistence use by CMER residents beyond reserve boundaries, i.e. in a second home in the nearest town), the forbidding of timber companies to enter the reserve, and limiting of agricultural production to $10 \%$ of each landholding, and cattle to $50 \%$ of agricultural areas, also underscores the heavy focus on extraction. The plan reflects the findings of numerous studies (Peters, et al., 1989; Anderson \& Ioris, 1992; Clay, 1992; but see Browder, 1992; Homma, 1993) that emerged during this period noting the potential of NTFPs to serve as a path to sustainable development, one which would raise forest household incomes in ways that were consistent with current livelihoods and use of social spaces, and conserve forests.

However, in 2000, the Utilization Plan lost its authority as a regulatory instrument when the National System of Protected Areas law (SNUC - law 9.985) classified the extractive reserve as a "sustainable use" protected area, a category which allows for varying forms and degrees of exploitation and conservation of natural resources (MMA, 2000). Despite no conceptual impact on the CMER, this law articulated forms of regulation and decision making within the reserve to be implemented via management plans and deliberative councils, respectively. These new governance mechanisms reduced the role of local social organizations in decision-making, instead distributing these powers 
across a diverse set of local and regional stakeholders.

Since the establishment of the reserve, demographic changes have also taken place. A study produced by the National Council of Rubber Tappers (CNS, 1992) shortly after the reserve was established estimated that 1,838 families lived in the CMER, spread over 1,444 landholdings (colocações), with a population of 12,017 . Approximately $60 \%$ of the population was under 18 years of age, and $38 \%$ between 18 and 62 . A more recent study conducted in 2009 (SEMA, 2010) found only a slight drop in the number of families to 1766 , but a near 33\% drop in inhabitants to 8,220. In 2009, approximately $42 \%$ of the populations was 18 or younger, while $58 \%$ were between the ages of 19 and 60. This same study suggests that the population decrease might be linked to a fall in birthrates, but also the out migration of reserve inhabitants, due to poor economic conditions and younger children seeking levels of education not offered in the CMER. Notwithstanding this drop, the study found that a majority of families remain on the same landholding they occupied when the reserve was established, suggesting a stable family residence pattern with limited turnover.

\section{Non-timber forest product development in the CMER}

The role of the extraction and sale of rubber in the socio-economic and cultural development in Acre over the past 150 years has been well documented (e.g. Santos, 1980; Weinstein, 1983; Bunker, 1984; Bakx, 1986; Dean, 1987). These scholarly works detail the mass migration of poor farmers from the northeast of Brazil to the region to supply labor to collect, or "tap", rubber, the debt-peonage relationships that bound rubber tappers to rubber barons, who owned the seringais, and how they were exploited through the aviamento debt-provisioning system (but see Barham \& Coomes, 1996), and the boom-bust cycles that characterized rubber production in the Amazon. They provide a historical foundation through the lens of diverse disciplines for understanding the role of NTFPs, particularly rubber, in the livelihoods of rubber tapper households when the CMER was established.

Research conducted at or near the time of the establishment of the CMER provides more recent context for understanding the socio-economic and cultural role of NTFPs. Studies demonstrated the vast use and knowledge of plant (Kainer \& Duryea, 1992; Ming \& Amaral Junior, n.d.) and animal (Medeiros \& Garcia, 2005) resources by reserve inhabitants. The ethnobotanical study by Kainer \& Duryea (1992) in particular suggested the potential development of a diversified extractive economy beyond rubber and Brazil nuts. Complementing these studies that focused on household use and consumption, a National Council of Rubber Tappers (CNS, 1992) CMER survey documented the critical role of extractive products for household income. At that time, NTFPs accounted for nearly $70 \%$ of household income (44.7\% rubber and $24.6 \%$ Brazil nuts) while crop and animal production contributed $21 \%$ and $8.5 \%$ respectively. The CNS argued for the need to "transform traditional extraction into modern" and to break down the traditional aviamento system that characterized the extractive economy and kept many families in poverty (CNS, 1992, p. ix). 
Campbell's (1996) research in the CMER and nearby Chico Mendes Agro-Extractive Project conducted in 1991 and 1994 documents early attempts regarding how the extractive economy might be transformed. The establishment of the Xapuri Agro-Extractive Cooperative (CAEX) in 1988 helped many rubber tapper households break often exploitative economic ties with itinerant traders and local merchants, allowing them to earn higher prices for rubber and Brazil nuts, and pay a lower price for basic supplies, such as kerosene, coffee, sugar and batteries. Through Project Brazil Nut, heavily supported by international non-government organizations such as the Ford Foundation, Inter-American Foundation and World Wildlife Fund (WWF), CAEX placed trading posts in five seringais within the municipality of Xapuri hoping to compete with traders and reduce the need for households, often without animals for transportation and located several days' journey from the city, to travel to the main CAEX supply store in the city of Xapuri. Notwithstanding some initial success, the posts eventually failed due to capitalization problems and poor administration.

Campbell also analyzes an early attempt by CAEX to "modernize" the extractive economy, with the development of a Brazil nut processing factory in Xapuri. The plant, designed for shelling, drying and packaging activities, was established to add value locally and help rubber tappers gain a greater share of the final selling price. Mini-Brazil nut shelling plants were also inaugurated in five forest areas and a few in-home shelling stations were also developed. All contributed to higher incomes for participating families, and helped empower women in particular, as they gained direct access to income through home-based cottage industries. Ultimately both the urban plant and "forest factory" concept ceased operations due to financial and administrative problems.

\subsection{NTFP development: challenges to product diversification}

Identifying potential products to diversify household income was a key priority for developing the extractive sector in the reserve (IBAMA, 1995); however, many studies have documented the challenges to accomplishing this. Wallace \& Gomes (2016) and Wallace \& Ferreira (2016) (fieldwork for both studies conducted in 1996-97) examined the potential for households to extract and sell three palm fruits: açai (Euterpe precatoria Mart), bacaba (Oenecarpus mapora Karsten) and patauá (Oenocarpus bataua Mart.). These fruits were already extracted by many households and consumed as a thick juice; thus, residents had knowledge of them in terms of when they ripen and how to extract them with limited damage to the fruit. Wallace \& Gomes (2016) examined the market systems for Brazil nuts and rubber and considered what could be learned from these systems in contemplating the collection and sale of other NTFPs. These studies highlighted the unique social and economic role of rubber and Brazil nuts in many households: they were non-perishable and had guaranteed markets, or, in other words, a guaranteed return on labor, however low the selling price might be. By pledging production to itinerant traders and urban merchants, these two products also provided critical access to credit and/or supplies in non-harvest seasons (cf. Campbell, 1996). 
A number of challenges to selling the three palm fruits were identified. Wallace \& Ferreira (2016) found that while many households extract and consume these fruits, not all do, and consumption is irregular if not rare. Extraction for commercialization of all three palm fruits requires climbing multiple trees, with açai and patauá particularly difficult due to their height, reaching 20-25 meters. A number of households cut trees to get to the high fruit bunches. Population density of the palms could also be an adverse factor: transects conducted to estimate production potential demonstrated relatively low market values for most households. Concomitantly, Wallace \& Gomes (2016) noted a number of constricting issues: extractive activities for fruits would compete for labor in Brazil nut and rubber collecting households, and high perishability of the fruits would make selling particularly difficult: many households lacked containers to transport the fruit, access to transport, and means to communicate with buyers, critical for getting fresh fruit to buyer hands. A later ecological study in the CMER suggested that açai population densities and species structure was favorable for sustainable management, particularly in lowland areas (Rocha, 2004). The development of the açai industry in the region around CMER continues to develop, with support from federal and state agencies, although activity is without monitoring and economic impacts have been limited.

Leite's (2004) study of copaiba oil (copifeira $s p p$ ) identified a different set of issues that may limit potential management and commercialization of extractive products. His study responded to the Acre state Forest Government identification of priority NTFPs, including copaiba oil, for developing management plans and commercialization based on market demand, the potential for sustainable ecological management, and species density. Unlike palm fruits, copaiba oil is not perishable, and Leite suggests the adaptation of technologies for non-predatory extraction are relatively cheap and easy to use, and households can be trained to map landholdings. However, what poses the greatest challenge is the development and execution of a management plan as required by IBAMA. Management Plan requirements include more mundane issues such as the use of safety equipment, but also more onerous requirements, such as specific types of personal identification that many lack, and the need to contract for costly inspections of in-forest management processes, estimated at $\mathrm{R} \$ 45,000$ (US\$15,000 with an approximate exchange rate of $\mathrm{R} \$ 3.00$ equals US\$1.00) for copaiba (costs assumed by supporting organizations). Despite these challenges, the management plan for copaiba approved by IBAMA has improved the income for some reserve households (Leite, 2004). These studies suggest both the challenges and potential of NTFP diversification, and also the significant financial and technical support required.

\subsection{NTFP development: adding value to traditional products}

A number of initiatives and investments have aimed to help reserve residents gain a better price for rubber and Brazil nuts. As noted above, CAEX helped increase, however small, the prices rubber tappers received for rubber and Brazil nuts while lowering supply prices. Although in-forest trading posts, initially run by CAEX and then by the Association of Inhabitants of the Extractive Reserve in Xapuri (AMOREX, now AMORPREX) have had 
mixed success due to capitalization problems, they created alternative market systems and benefitted households with higher prices and improved bartering positions (i.e. Campbell, 1996; Wallace, 2004; Wallace \& Gomes, 2016).

Other initiatives have also had important impacts. Upon election as Acre Governor in 1999, Jorge Viana pursued a policy of sustainable development fostering multiple forest industries - both non-timber and timber (Kainer et al., 2003). The Forest Government's policies and programs were part of the larger vision of "neoextractivism" (Rego, 1999) that considered how the forest dweller's "cultural universe" was embedded in his/her relationship with nature (Rego, 1999, p. 65) and argued for a vision of sustainable use of forests that included not only extraction, but also agroforestry and other complementary activities. The Forest Government also supported the FLORA Fair, that promoted the commercialization of regional NTFPs by traditional peoples and urban artisans, but also the region's historical ties to the forest, and with a focus on contributions of forest populations to local cuisine and cultural traditions (Wallace et al., 2008).

Viana's strong ties to the rubber tapper social movement in Xapuri led to a number of initiatives and policies to support the extractive sector. The first was the establishment of the new Executive Secretary of Forestry and Extractivism (SEFE), which would have agents working closely with forest communities in-forest. A second key initiative was the Chico Mendes Law (Law 1.277 dated January $13,1999)$ that established a $R \$ .40$ subsidy payment per kilogram of rubber. The rubber had to be sold to a local cooperative or association to receive the subsidy; thus, CMER residents needed to become a member of CAEX and/or a local association and sell to CAEX in Xapuri or at in-forest trading posts. The subsidy was raised to $\mathrm{R} \$ .60$ and then $\mathrm{R} \$ .70$ per kilogram in the following years.

Past studies help understand the important impacts of the rubber subsidy. Wallace (2004) found that the subsidy helped many families earn a higher price for rubber, and simultaneously dramatically shifted trading patterns in the forest, with CAEX now dominating rubber trade. However, the subsidy did not result in bringing families back into rubber production. Wallace's (2009) longitudinal study tracking 24 reserve households from 1996-2006 shows a more complex picture of income earning activities in general (including off-landholding income), and also rubber subsidy impacts. Extraction (almost all related to rubber and Brazil nut production) as percent of productive income fell from $46 \%$ to $17 \%$ of income from 1996-2006, while animals, including cattle and smaller animals remained relatively stable at $22 \%$; most strikingly, income from off-farm labor, rose from just $19 \%$ to $60 \%$ of productive income. Examining shifts in total income, both productive income and payments from social programs (such as retirement, health and maternity payments, and Bolsa Familia, a national program to support households with children in school) over this 10-year period, extractive income as a percent of total income fell from $35 \%$ to $9 \%$ while payments from social programs increased from $25 \%$ to $44 \%$, off-farm labor income grew from $14 \%$ to $31 \%$, and income from animal production fell from $17 \%$ to $12 \%$. The findings suggest the dynamic livelihood strategies of reserve households, as they continue to engage on-farm productive activities, both extractive and animal production, while identifying new opportunities to sell their labor and gaining access to critical social payment programs. 
Looking more specifically at extractive income helps better understand the rubber subsidy impact. Total rubber production among all families fell from 1996 to 2001, and from 2001 to 2006, despite the subsidy increase during both periods. The number of households extracting rubber fell by half over the 10-year period: nearly all 24 households tapped rubber in 1996, falling to 16 in 2001, and to 12 in 2006. While both higher and lower income households participated actively in rubber extraction in 1996, higher income households abandoned rubber as an income earning strategy over the period, while lower income households increased production. While suggesting that rubber extraction is declining in the three forest areas of the study, it also demonstrates that the poorest households rely heavily on rubber sales for income. This same trend held with extractive income more generally, although Brazil nut extraction was still practiced by some higher income households. Nearly all higher income households were investing labor in off-farm activities outside their landholdings and gaining a greater share of income through cattle sales. Concomitantly, Wallace (2004) found that an increase in household income from off-farm labor resulted in a fall in percent of total productive income from extraction. Da Silva (2013) also demonstrated the positive impact on income the rubber subsidy had in communities more distant from urban areas, although study participants noted it made a small contribution to the household income. Further, Sabogal et al. (2015) in a study of nearly half of households across the reserve found that $21 \%$ of households collected rubber at the time of the interview and $18 \%$ had benefitted from the rubber subsidy in 2014.
Another important Forest Government initiative to stimulate rubber production in the reserve and raise rubber prices was the construction of the Natex condom factory in Xapuri. The factory, a community-private-public partnership, opened in 2008, purchases rubber in liquid latex form and converts the latex into condoms, which are sold to the Brazilian National Health Agency (Schmink et al., 2014). Jaramillo-Giraldo et al. (2017) estimate that the factory created 150 local jobs and benefitted over 700 of a total 2000 families in the CMER. Although the authors argue that the factory is not sustainable without a subsidy, Da Silva (2013) demonstrated how Natex has had an extremely positive impact in the CMER. Households in one forest area earned a subsidy premium of $\mathrm{R} \$ 4.20$ per liter of latex sold in 2011, and noted the latex subsidy made a large contribution to household income. Notwithstanding, more recent reports (Lima, 2016) suggest that due to the pending privatization of Natex, the factory is no longer purchasing latex from rubber tappers in the CMER.

The Acre government has also supported the Brazil nut sector through the investment in Brazil nut processing plants in municipalities that serve CMER residents, and played a critical role in supporting Cooperacre, a cooperative that supports the collection and commercialization of extractive products, with numerous local associations and cooperatives, such as CAEX, as member organizations (Schmink et al., 2014). Brazil nut certification has also been initiated to increase Brazil nut prices. Duchelle et al. (2014) note that Organic, Fairtrade and Forestry Stewardship Council certification have been implemented in Acre, with the support of diverse state, federal and international government and non-government organizations. However, due 
to cooperative failure in 2007 , many households did not receive a second payment related to certification. Still, preliminary results from an earlier longitudinal study (Cavalcanti et al., 2008; see also Maciel, 2011) from 1995/96 to 2005/06 noted the important contribution that certified Brazil nuts could make to household income. For those families that sold certified Brazil nuts, their income from Brazil nut certification amounted to nearly $30 \%$ of their household income, and total Brazil nut sales (including non-certified sales) accounted for $44 \%$ of household income. This figure compares favorably to non-certified Brazil nuts sales amounting to $22 \%$ of household income in 1995/96. For households that earned income from Brazil nut certification, extractive activities grew as a percent of total income over this period from $43 \%$ to $56 \%$. Sabogal et al. (2015) found that $60 \%$ of 738 households collected Brazil nuts, receiving a price per lata, or bucket (approximately 11 kilograms of Brazil nuts), varying from $R \$ 16.50$ to $R \$ 43.25$ with an average household production of 172 latas per season and an average price of $\$ 29.50$ per lata (the study did not note whether any households received a premium price for certification). Although not all households have Brazil nuts on their landholdings, the study suggests how NTFPs remain an income staple for many families.

NTFPs hold historical significance for reserve households and continue to provide critical income to many. Substantial state investments in rubber subsidy programs and infrastructure, as well as in the development of organic and certified Brazil nuts, have helped rubber tappers earn greater value for rubber and Brazil nuts. Nonetheless, initial enthusiasm and high expectations for product diversification to increase income from NTFPs have not been met, and the varied investments to support the extractive sector have not created a foundation for long-term sustainability.

\section{Contexts and reasons for cattle ranching expansion in the Chico Mendes Extractive Reserve}

Over the past decades, large-scale cattle ranching activity is the main cause of deforestation in the Amazon (Schmink \& Wood, 1992; Faminow, 1998; Barreto et al., 2005). Now, however, ranching is no longer confined to large-scale landowners, and has grown among other groups, such as smallholder agriculturalists who historically focused on crop cultivation but have now turned to cattle (Walker et al., 2000; Perz, 2002; Ludewigs et al., 2009; Pacheco, 2009). Likewise, forest communities with historical roots in extractive economies, in some contexts, have turned to small-scale cattle raising to diversify livelihoods as a means to raise incomes (Gomes, 2001; 2009; Salisbury \& Schmink, 2007; Vadjunec et al., 2009; Gomes, et al., 2012a; 2012b). This convergence into cattle across sociocultural distinct groups (Gomes, et al., 2012b; Hoelle, 2015) has been driven by increased demand from growing regional and international markets for beef (Nepstad et al., 2006; Smeraldi \& May, 2008; Walker et al., 2009; Pacheco \& Poccard-Chapuis, 2012). Extractivist community cattle ranching practices reflect unstable prices, and more generally a lack of market development for NTFPs. The emergence of cattle production in the CMER raises new concerns regarding transforming livelihood systems and food security, while highlighting new environmental challenges for the extractive reserve. 
The eastern part of Acre lies at the westernmost limit of the "arc of fire and deforestation" in the Brazilian Amazon. Eastern Acre, where forest dwelling communities, cattle ranchers and colonists coexist, has experienced massive changes in land use since the 1970s. The CMER sits at the limit of the frontier, rooted in the history of the grassroots rubber tapper movement, but also in the history of regional land-use change (Calaça, 1993). The CMER has proven efficient in securing the land rights of rubber tappers, while also serving as a barrier to contain large-scale deforestation in the region.

According to measurements of deforestation from 1988 (two years before the creation of the CMER) to 2010, the accumulated deforested area accounts for 76,430 hectares, representing 8.19\% of the total area of the CMER. This is below the limits established in recent legislation (SEMA, 2010); thus, the CMER has thus far shown to be an effective model for environmental conservation. However, the dynamics of deforestation across the reserve have not been homogenous. The most deforested seringais are concentrated in the southern part of the reserve, following BR 317, and closer to the cities on the periphery of the CMER - Xapuri and Brasiléia - (Sassagawa, 1999; Gomes, 2001; Vadjunec et al., 2009; SEMA, 2010), where extensive small-scale cattle ranching and agriculture dominate among family income generation options (Gomes, 2001).

The regional and local socio-economic factors that have affected land-use change in eastern Acre have both directly and indirectly influenced land-use change within the CMER. Analyzing data from CMER censuses carried out by IBAMA (in 1995, 1998 and 2000), Gomes (2001, p. 111-113) measured land-use change in four seringais with the highest deforestation for these three different periods and found that small-scale cattle ranching was increasingly transforming livelihoods systems. Pasture creation, and thus, cattle raising, as well as agricultural production, increased while extraction of NTFPs, mainly rubber and Brazil nut, suffered a drastic decrease. From 1995 to 2000 the average production of cattle in each seringal increased by $120 \%$, while rubber production decreased by $88 \%$ and Brazil nut production fell by $32 \%$.

As noted above, the CMER Utilization Plan was the first land-use regulation instrument jointly created by rubber tapper associations and government representatives, in which federal environmental legislation and traditional rubber tapper resource utilization were reconciled (IBAMA, 1995). The plan sets forth an upper limit of $10 \%$ of deforested area per landholding (of an estimated 300-400 hectares), including residential clearing, pasture, agricultural and agroforestry plots, and abandoned fields; a small number of cattle were allowed to improve the household daily diet and facilitate transportation of production. Notwithstanding these regulations, the most recent socioeconomic survey of the CMER (SEMA, 2010) suggests that of the 46 seringais that comprise the reserve, 14 have surpassed the deforestation limit, a result of the increased economic importance of small-scale ranching. According to the same study, across the CMER, cattle ranching represents $35 \%$ of the family income, equal to all extractivism production (35\%), followed by agriculture (14.4\%), government benefits and retirement (13.4\%), and wages (2.2\%).

A number of studies have argued that the growth in cattle production in the CMER has to do with economic, cultural and political reasons, which privilege cattle over rubber and NTFPs 
more generally (Gomes 2001; 2009; Ehringhaus, 2005; Salisbury \& Schmink, 2007; Vadjunec et al., 2009; Gomes et al., 2012a; 2012b). In this context, the CMER and other extractive reserves cannot be considered "isolated islands," removed from land use dynamics and economic forces that dominate regional landscapes. The dominant market opportunities in Acre often are not based on sustainable strategies but instead are influenced by local and regional economies operating outside of the reserve. Despite Forest Government investments in infrastructure and subsidy payments for the extractive sector (Kainer, et al., 2003), unstable prices and limited options for diversifying extractive production have made cattle a more attractive livelihood option for forest extractivists. Cattle can provide steady income and serve an insurance function for families with sudden crises when cash is needed. Cattle can be sold at any time of the year and can be walked to town (or hauled by cattle buyers), unlike seasonal production or the need for producers to haul NTFPs to urban areas for higher prices (Gomes et al., 2012b). However, a principle consideration is not simply the adoption of cattle as an investment strategy, but the extent of the investment and relative proportion of household income, as cattle-raising gains increased economic rationality and function for families in the reserve.

Cattle ranching expansion has contributed to the complexity of rubber tapper identity, which is fomenting tensions among residents of the CMER, and between residents and outside actors such as the state government and NGOs (Gomes et al., 2012b). Among CMER residents, perspectives on rubber and cattle often break along generational lines. The development perspectives of new generations do not necessarily reflect the vision of the rural unio- nists from 30 years ago, the vision that resulted in the creation of the reserve. This new generation of residents, not directly linked to the history of the social movement, has advocated a developmental vision centered on divergent values of forest identity, with a growing absorption and exercise of "cowboy culture" in the forest - contrasting with the principles of development defined 30 years ago (Gomes et al., 2012a; Hoelle, 2015; Wallace \& Gomes, 2016). Thus, cattle ranching, symbolic of the rubber tapper movement's struggle against ranchers, cannot be viewed as an isolated problem, nor just as a disruption with the principles of sustainability of the CMER. The question of cattle in the CMER needs to be understood and approached as part of a complex, heterogeneous and changing productive and social system that must be addressed through the shared management model of the extractive reserve concept.

\section{The course of community-based timber initiatives in Acre}

Some of the Amazon's earliest CBTM initiatives were born in Acre during the 1990s. Shortly after the establishment of a variety of sustainable-use protected area systems in Brazil (e.g. agro-extractive settlements in 1987 and extractive reserves in 1989), parties at the 1992 United Nations Conference on Environment and Development (UNCED) wrote the concept of sustainable forest management into the global development agenda. From there, the Program to Support Sustainable Forest Management in the Amazon (ProManejo Program) incentivized pilot projects, including those of CBTM in Amazon forests (Stone, 2003; Pi- 
ketty et al., 2015). The purview of Brazilian national forest policy was IBAMA, and in 1995, it drafted a specific management plan template (the Plano de Manejo Florestal Sustentável; PMFS) required of all logging industries, later simplified (PMFSimples) to accommodate the realities of smallholders and communities experimenting with logging in the Amazon (Stone, 2003). Finally, during that period, the Brazilian Forest Code was revised for the first time since 1965.

\subsection{The Acre state forest government and timber development}

During the 2000s, the Forest Government embraced the above-mentioned shifts in national level forestry policies and further aimed to strengthen state forest-based development and conservation initiatives, which included the development of CBTM projects. The state invested in training programs, infrastructure, and technology development for timber production (Kainer et al., 2003), which included furniture production poles and a certified flooring factory (Salisbury \& Schmink, 2007; Stone et al., 2007). The Forest Government sanctioned political, technical, and financial support for low intensity logging in diverse forest-based communities (but not extractive reserves) (Stone, 2003; Duchelle et al., 2011). This agenda received US $\$ 79.2$ million from the Inter-American Development Bank (IDB) for sustainable development initiatives, including US\$7.1 million to allocate specifically toward forest management and extractivism (Kainer et al., 2003).

However, the first CBTM experiments took seed before CBTM gained traction with the Forest Government, when timber extraction in protected forests was yet a highly contentious proposal. But, low intensity timber harvest appealed to some rubber tappers as a much-needed income source to complement extractive and subsistence activities. Especially considering land use restrictions written into the reserve systems, alternative livelihood options consistent with extractivism were limited. Some actors, including organizational partners of these early projects, also viewed timber as an economic strategy to compete against the growing expansion of cattle production (Piketty et al., 2015).

Between 1988 and 2003, five CBTM experiments were initiated in Acre, including in public forests designated for sustainable use (agro-extractive settlements - PAEs and state forests), and privately-owned forested lands (agricultural colonization projects - PDAs; Stone, 2003). Of these, PAEs Porto Dias and Cachoeira, both located near the CMER, emerged as the largest projects and most well-endowed by external support (Medina \& Pokorny, 2011). Cachoeira was the first CBTM project to develop with the blessing of the state (Stone, 2003). Thus, the communities with projects preceding the Forest Government depended heavily on NGOs and other civil organizations to provide critical assistance in terms of technical expertise, financial support, training and capacity building, access to FSC certification, and network building across forest communities engaging with the activity (Stone, 2003).

The objective of the early CBTM model was to prepare community members to perform all forestry activities, from logging operations to selling processed timber. Early projects exposed some of the challenges inherent to CBTM initiatives, including: the technical complexity of timber harvest, the need for administrative capacity, and the critical role of 
community organization. The relatively well-organized communities of Porto Dias and Cachoeira became emblematic cases of the CBTM model in the region (Stone, 2003). Local associations in Porto Dias and Cachoeira both partnered with the Amazon Workers Union (CTA), a local NGO, and WWF, which supported these communities with the preparation of forest management plans and certification. Eventually, the Porto Dias Association purchased an old-fashioned sawmill while the association in Cachoeira tried to contract out to external sawmills (Piketty et al., 2015).

This operational model did not survive in these projects (Piketty et al., 2015), a trend reflected elsewhere in Amazonia (i.e. Medina et al., 2009; Hajjar et al., 2013). Community associations faced obstacles identifying buyers and negotiating contracts, among other challenges. With support from WWF, a network of smallholders (called the Group of Forest Producers of Acre - GPFAC) organized to assist community forestry enterprises navigate the complexities of smallholder timber production. In 2007, this network became Cooperfloresta, a nonprofit cooperative that has since managed community-based logging operations across the state. As of 2012, Cooperfloresta has operated in all phases of production, including project planning, inventory, monitoring, transporting, sawing, and timber trading (Hechenberger, 2013; Piketty et al., 2015).

The formation of Cooperfloresta represented a shift in the CBTM model in Acre. Over time, more of the decision-making, negotiating, and operational activities previously made by community associations were subcontracted out. Since 2009, associations in Cachoeira and Porto Dias decided to subcontract Cooperfloresta to carry out timber harvesting and transport (Piketty et al., 2015).

These pilot projects received substantial initial inputs of financial capital (e.g. for inventories and management plans) and capacity building without which forest communities might have been prohibited from pursuing organized CBTM. Cachoeira received the biggest investment of $\mathrm{R} \$ 1.6$ million, Porto Dias the third largest at nearly R $\$ 1$ million (Medina \& Pokorny, 2011). Despite these major investments, the tendency to contract external actors in logging operations signals the many challenges to feasibility of low-intensity, sustainable community timber harvest in extensive contiguous forests and destined for external markets (see Medina et al., 2009; Hajjar et al., 2013a number of challenges face communities wanting to initiate or maintain formal, community-based forest management. Through a grounded theory approach, this paper uses three case studies of community forest management models in the eastern Amazon to create a framework showing challenges faced by communities at different phases of formal management. The framework shows that, in the development phase, four root problems (land ownership, knowledge acquisition, community organization, and adequate capital; and Pokorny \& Pacheco, 2014 for further discussions on challenges in CBTM).

Nevertheless, CBTM projects can support extractivist households with, at a minimum, much needed supplemental income. In 2010 in Porto Dias, participating households earned approximately US $\$ 4,506$ for their timber, while in Cachoeira the comparable figure was US\$3,294 (from 2009 harvests, value adjusted). However, these benefits were also subsidized by the state, and net values 
hover around national minimum wage rates (see Piketty et al., 2015 for details).

\subsection{Community-based timber management in the Chico Mendes Extractive Reserve}

Notably, logging is fairly well established in other categories of sustainable-use protected areas, but timber harvest for commercial use (vs. strictly subsistence-based harvest, which is legally permitted) has been approved in only a few Amazonian federal extractive reserves. In addition to the CMER, three others have initiated CBTM projects: Verde Para Sempre and Mapuá in Pará, and Ituxi in Amazonas (IFT, 2016).

Discussions of implementing CBTM in the CMER initiated during the early 2000s, but CMER residents rejected any serious proposals to participate in logging at the time (Stone, 2003). Nevertheless, the topic of logging in the CMER has lingered in the regional collective consciousness for nearly two decades, and the CMER management tools (the CMER Management Plan and Utilization Plan) reserve space to incorporate commercial timber management into the CMER, albeit under strict guidelines. Rules require a Community PMFS (PMFSComunitário) and its approval by the federal regulatory agency, ICMBio. The 2006 CMER Management Plan acknowledges that timber management could supply income to CMER residents, yet not without caution, warning that specialists and CMER community leaders viewed timber management as a potential major threat to the reserve's social, economic and environmental sustainability (MMA, 2006). The Instrução Normativa ${ }^{\circ} 16$ (2011) by ICMBio generated an additional tool to assist managers to integrate legal commercial timber management into federal extractive reserves, outlining a road map of guidelines and administrative processes to attain formal ICMBio approval of community PMFSs (ICMBio, 2011).

Some of the same concerns that mobilized early CBTM projects (e.g. increases in cattle production) elsewhere continue to motivate present day discussions around commercialization of timber in the CMER. Legal, low-intensity timber harvest using reduced impact logging guidelines is considered by some a strategy to mitigate deforestation by minimizing the financial need to convert forests to pasture, through timber-based income and regulation of illegal logging (ICMBio-MMA, 2016), an activity not well documented yet well known to occur within the CMER. The threat of illegal deforestation is quite prominent in the CMER: a study of illegal use of natural resources in 118 federal protected areas of the Brazilian Amazon (91.5\% of total federal PAs in the Brazilian Amazon; among those evaluated, 42 were extractive reserves) during the 2010-2015 period found that the CMER was among the top four PAs with the highest frequency of illegal activities related to the suppression and degradation of vegetation (which includes illegal logging, deforestation, and forest degradation) (Kauano et al., 2017). Indeed, logging projects in the aforementioned federal extractive reserves and similar forest communities (i.e. Humphries et al., 2018) have demonstrated promising outcomes thus far (IFT, 2016), and could similarly benefit the CMER.

The recent logging projects in the CMER have been funded by Inter-American Development Bank, Program for Sustainable Development in the State of Acre (PSDA; phase II) in partnership with 
the Acre state government (Portal do Governo do Acre website, http://www.ac.gov.br accessed July 25, 2018). The earliest pre-harvest activities (e.g. inventories) initiated in the municipal zone of Xapuri around 2009, followed by CMER communities in Brasiléia/Epitaciolândia and Assis Brasil. Cooperfloresta developed the PMFS and Annual Operation Plan (POA) for each of these projects, as well as managed logging operations in CMER Xapuri municipality in 2014, the only harvest cycle completed to date.

In November 2011, the CMER Xapuri association (AMOPREX) obtained legal recognition of their community PMFS involving 62 families to explore a total area of $18,772.74$ ha. The following year, their first POA was legally authorized (via Authorization of Forest Exploration - AUTEX), thus liberating loggers to initiate cutting, in this case to exploit an area of 918 ha and an estimated $12,998.47 \mathrm{~m}^{3}$ of timber. However, technical issues in the community PMFS and the poor transportation conditions demanded modifications to the AUTEX and thus delayed the first harvest until 2014. Until resolved, the challenges of transporting logs across the river also complicated the securing of wood buyers (S. Hechenberger/SEMA, and former rep. of Cooperfloresta, personal communication, July $25,2018)$. The final volume harvested in 2014 was $4,319 \mathrm{~m}^{3}$ (ICMBio-MMA, 2016). Following the 2014 harvest (and expiration of AUTEX, valid for 12 months), logging activities came to a halt, until recently. This project and alternative iterations of its original form presented in the PMFS, were planned for discussion in January 2018 (Dionísio Barbosa de Aquino/Cooperfloresta, personal communication,
December 12, 2017), and logging was re-initiated in CMER-Xapuri in July 2018 (S. Hechenberger/ SEMA, and former rep. of Cooperfloresta, personal communication, July 25,2018 ), though we do not have further details.

Prior to logging in CMER-Xapuri, in 2013 Cooperfloresta was contracted to also map forest inventories on 41 landholdings in another set of communities in the CMER, pertaining to the CMER-Brasiléia/Epitaciolândia association (AMOPREBE). Among other reasons, divided positions on logging and related community disorganization prevented ICMBio from authorizing harvest. ${ }^{2}$ AMOPREBE continues to wait for authorization to $\log$. We know less details about the project in Assis Brasil, except that its trajectory has closely resembled that of the Brasiléia/Epitaciolândia project and similarly awaits authorization.

Like the early CBTM initiatives, the original intent of these CMER logging projects has been to engage CMER extractivists in timber management activities. Both AMOPREX and AMOPREBE signed agreements with Cooperfloresta to develop all the necessary activities for the project beneficiaries to implement the management activities, ranging from training and harvest operations to commercialization. However, the timber management carried out in CMER-Xapuri had little local participation in operations, and even generated controversy, perhaps suggesting premature implementation (ICMBio-MMA, 2016). Similarly, in CMER-Brasiléia/Epitaciolândia, participation in pre-harvest activities was generally limited to attending a handful of meetings, and many residents expressed frustration with government (vs. resident)

${ }^{2}$ See Cooper \& Kainer (2018) for details about this logging project and varied resident perceptions of it. 
control to authorize timber management, harvest, and commercialization, with little local input in these decisions (Cooper \& Kainer, 2018).

Following the 2014 CMER-Xapuri harvest, a class from a university-level forestry course at the Federal University of Acre (UFAC), in conjunction with Cooperfloresta, WWF and ICMBio, conducted interviews in 32 households that had logged. Their findings suggest that among individuals interviewed, the majority (47\%) would have preferred to engage at least in the timber harvesting and commercialization activities; meanwhile, $44 \%$ were satisfied with simply selling the timber harvest rights to a third party (i.e. Cooperfloresta) to harvest. This study also indicated disagreement among residents over the extent to which the harvest benefitted household income, and whether or not households would pursue future harvests (UFAC, 2017).

Residents of CMER-Brasiléia-Epitaciolândia area shared similarly mixed views about the endeavor during its pre-harvest phase. Participants were primarily motivated by the additional income, and indeed, these households showed greater financial need compared to non-participating households. Meanwhile, non-participants argued that the quoted price of timber $\left(\mathrm{R} \$ 60 / \mathrm{m}^{3}\right)$ was unacceptably low (Cooper \& Kainer, 2018). In terms of addressing clandestine logging in the CMER, the legalization of low-intensity logging was perceived as important among several project supporters; legalization would grant secure and legal access to needs-based timber income that may otherwise be sought reluctantly through informal means (Cooper \& Kainer, 2018). However, such households are likely not the biggest culprits of illegal logging in the CMER, which along with other infractions to the rules, largely goes unmonitored (Vadjunec, 2011).
Despite potential benefits, even members from participating households in both CMER projects reported a variety of concerns and uncertainty about potential environmental impacts of logging (especially from skidder use), and overall, many decisions to participate represented a complex analysis of environmental and financial trade-offs (Fantini \& Crisóstomo, 2009; Cooper \& Kainer, 2018).

\section{Discussion and final considerations}

This article explores three trajectories of socio-economic development in the CMER - NTFPs, cattle ranching, and CBTM. These interconnected and dynamic trajectories illustrate the challenges and dilemmas of linked conservation and development initiatives in the Amazon. Nearly three decades since the death of Chico Mendes and the establishment of the CMER, it is clear that there is now great socio-economic diversity across the reserve's 46 seringais and among neighboring households, and this diversity requires multiple pathways to improve reserve livelihoods.

Table 1 provides a summary of the three trajectories, including the principal drivers and polices that have shaped each, and the positive outcomes of the policies as well as continuing challenges and lessons learned. Here we explore some of the key developments in each trajectory as well as final considerations for thinking about the future of the CMER.

Initial investments and policies to strengthen the NTFP sector helped transform the market system for the two key commercialized extractive products: rubber and Brazil nuts. The capitalization of CAEX, and subsequently Cooperacre, the establishment 
Table 1 - Summary of three trajectories of economic development in the Chico Mendes Extractive Reserve.

\begin{tabular}{|c|c|c|c|c|c|}
\hline Trajectory & Drivers & $\begin{array}{c}\text { Policies and } \\
\text { Projects }\end{array}$ & $\begin{array}{c}\text { Positive } \\
\text { Outcomes }\end{array}$ & Challenges & Lessons learned \\
\hline NTFPs & $\begin{array}{c}\text { - Historical regional } \\
\text { economic } \\
\text { importance of } \\
\text { extractive products } \\
\text { - Extractive products } \\
\text { embedded (at least } \\
\text { in the past and/or } \\
\text { older generations) } \\
\text { in rubber tapper } \\
\text { identity and culture; } \\
\text { - Acre state } \\
\text { government } \\
\text { policies promoting } \\
\text { productive and } \\
\text { sustainable use } \\
\text { of forests have } \\
\text { encouraged } \\
\text { extractive } \\
\text { development } \\
\text {-More generally, } \\
\text { ideologies of } \\
\text { sustainable } \\
\text { development and } \\
\text { forest conservation }\end{array}$ & $\begin{array}{l}\text { - Chico Mendes } \\
\text { Law - Rubber } \\
\text { subsidies } \\
\text { - State and NGO investment } \\
\text { in value-added activities } \\
\text { (in-forest technologies, } \\
\text { local factories) } \\
\text {-Certified Brazil nut } \\
\text { initiatives implemented and } \\
\text { higher incomes earned } \\
\text {-Local cultural events to } \\
\text { promote extractive culture } \\
\text { and economy }\end{array}$ & $\begin{array}{c}\text { - Income generation } \\
\text { - Livelihood diversification } \\
\text { - Safety net for poorest households } \\
\text {-Success in establishing } \\
\text { cooperatives to help receive better } \\
\text { prices for products and lower } \\
\text { prices for supplies. } \\
\text { - Some success in local value- } \\
\text { added processing and community- } \\
\text { private sector-state partnerships }\end{array}$ & $\begin{array}{c}\text { - Low returns on } \\
\text { labor } \\
\text { - Lack of product } \\
\text { diversification and } \\
\text { development of } \\
\text { markets } \\
\text {-Difficult to develop } \\
\text { management plans } \\
\text {-Unstable markets } \\
\text { for value-added } \\
\text { products } \\
\text {-Lack of } \\
\text { community-private } \\
\text { partnerships } \\
\text {-Administrative and } \\
\text { operational problems } \\
\text { with cooperatives } \\
\text { and local factories } \\
\text {-Certification } \\
\text { premiums not paid } \\
\text { to extractors }\end{array}$ & $\begin{array}{l}\text {-Development of a diversified } \\
\text { extractive economy requires } \\
\text { long-term investments in the } \\
\text { production and market chain- } \\
\text { - Cooperative administration and } \\
\text { management abilities need to be } \\
\text { strengthened to manage complex } \\
\text { community-based production } \\
\text { and marketing } \\
\text {-Community-based production } \\
\text { and commercialization } \\
\text { benefits due to assistance } \\
\text { from supporting organizations } \\
\text { to identify new markets that } \\
\text { add premium value through } \\
\text { certification programs, including } \\
\text { organic, fair trade and green/ } \\
\text { sustainable markets } \\
\text { - Private-community } \\
\text { partnerships can help revitalize } \\
\text { and stabilize markets. They must } \\
\text { be tailored to local social and } \\
\text { geographical contexts }\end{array}$ \\
\hline
\end{tabular}




\begin{tabular}{|c|c|c|c|c|c|}
\hline Cattle & $\begin{array}{l}\text { - Cattle ranching } \\
\text { and "cowboy } \\
\text { culture" are } \\
\text { predominant } \\
\text { economic cur- } \\
\text { rent drivers in } \\
\text { the region } \\
\text { - Sector has } \\
\text { well developed } \\
\text { markets with } \\
\text { constant demand } \\
\text { and good prices }\end{array}$ & $\begin{array}{l}\text { - No governmental or } \\
\text { grassroots experimental } \\
\text { projects have been de- } \\
\text { veloped for implemen- } \\
\text { tation in the reserve }\end{array}$ & $\begin{array}{l}\text {-Income generation; } \\
\text {-Savings mechanism to decrease } \\
\text { financial and economic vulner- } \\
\text { ability } \\
\text {-Low capital investment and } \\
\text { labor demand for cattle manage- } \\
\text { ment and transport of animals } \\
\text { to market }\end{array}$ & $\begin{array}{l}\text { - Conventional } \\
\text { extensive model } \\
\text { of cattle pro- } \\
\text { duction leads to } \\
\text { deforestation } \\
\text {-Land use regu- } \\
\text { lation tensions, } \\
\text { and conflicts } \\
\text { with the legisla- } \\
\text { tion and external } \\
\text { authorities } \\
\text {-Increased dis- } \\
\text { semination of } \\
\text { cowboy culture } \\
\text { especially among } \\
\text { young generation } \\
\text { of reserve resi- } \\
\text { dents }\end{array}$ & $\begin{array}{l}\text {-Remnants of conflicts be- } \\
\text { tween cattle ranchers and } \\
\text { rubber tappers create ideo- } \\
\text { logical impediments to wide } \\
\text { discussion of adoption of } \\
\text { better practices and regula- } \\
\text { tions for small-scale ranch- } \\
\text { ing in the reserve } \\
\text {-Low impact technologies } \\
\text { for smallholder cattle ranch- } \\
\text { ing are available and should } \\
\text { be considered at the outset of } \\
\text { discussion of cattle ranching } \\
\text { in the reserve } \\
\text {-Cattle ranching is already } \\
\text { a part of many household } \\
\text { decision-making processes. } \\
\text { For many households, it } \\
\text { does not represent a rupture } \\
\text { of principles of land use in } \\
\text { the reserve }\end{array}$ \\
\hline
\end{tabular}




\begin{tabular}{|c|c|c|c|c|c|}
\hline СВТМ & $\begin{array}{l}\text { - Acre state driven } \\
\text { policies } \\
\text { - Local demand } \\
\text { for income/in- } \\
\text { come-generating } \\
\text { opportunities } \\
\text { - High deforestation } \\
\text { rates and illegal } \\
\text { logging (the need } \\
\text { to regulate timber } \\
\text { extraction) }\end{array}$ & $\begin{array}{l}\text { - Logging projects ini- } \\
\text { tiated in CMER com- } \\
\text { munities in three serin- } \\
\text { gais: Xapuri, Brasiléa/ } \\
\text { Epitaciolândia, and } \\
\text { Assis Brasil }\end{array}$ & $\begin{array}{l}\text { - Income generation for house- } \\
\text { holds that participated in logging } \\
\text { project } \\
\text { - Potentially reduced illegal log- } \\
\text { ging and deforestation }\end{array}$ & $\begin{array}{l}\text {-Local admin- } \\
\text { istrative prob- } \\
\text { lems } \\
\text {-Incoherent } \\
\text { legislation } \\
\text {-Poor commu- } \\
\text { nication among } \\
\text { stakeholders } \\
\text {-Operational } \\
\text { procedures that } \\
\text { require high } \\
\text { investments } \\
\text {-Monitoring prob- } \\
\text { lems } \\
\text {-Differences in } \\
\text { philosophical } \\
\text { opinions about the } \\
\text { role of logging in } \\
\text { a Conservation } \\
\text { Unit }\end{array}$ & $\begin{array}{l}\text { - Greater investments in } \\
\text { communication/education } \\
\text { about timber economy may } \\
\text { clarify potential opportuni- } \\
\text { ties and constraints in timber } \\
\text { design - Deeper engagement } \\
\text { in deliberative processes } \\
\text { with CMER residents during } \\
\text { project design/development } \\
\text { may better align project } \\
\text { design with local context, } \\
\text { improving multi-stakehold- } \\
\text { er relations and reducing } \\
\text { conflict }\end{array}$ \\
\hline
\end{tabular}


of the state rubber subsidy and some initial, if not sustained success, in adding value through the development of local factories and certification initiatives, all were critical to support the NTFP sector. Research has suggested that these policies have benefitted some of the lowest income earners in the CMER, in particular those households without the education, skills or capital to diversify into other income-earning activities. However, significant challenges remain. The inability to sustain investments and NTFP market options is reflected in the continued difficulties in developing management plans for commercialization of products that might encourage and support diversification, and continuing challenges to establishing and maintaining linkages to markets. New extractive resource management technologies and green markets can help diversify the products and services that the forest can provide. Certification can play an important role in maintaining environmental services by incentivizing sustainable environmental practices over activities more damaging to the environment such as cattle production. Some success in the establishing of community-private sector partnerships in the extractive sector suggests that they be explored to identify new products and markets (Allegretti, 2011; Schmink et al., 2014).

The cattle ranching sector in Acre is growing, and state support, stable markets and income earning possibilities provide an incentive for CMER households to invest in cattle. Rubber tapper households have long viewed cattle as a safe investment of savings, with high liquidity to accommodate immediate cash needs, particularly for health emergencies (Gomes et al., 2012c). However, as "cowboy culture" has emerged as a prominent force and vision of development in eastern Acre (Hoelle,
2011), cattle-raising has also been incorporated into a growing number of reserve households as a primary productive strategy rather than a source of savings. The CMER management plan placed limits on agricultural production on landholdings, and some households have surpassed them. Increasing deforestation in the reserve due to clearing forest for pasture has focused the attention of diverse CMER stakeholders on cattle's place among the varied livelihood strategies of reserve residents. Cattle production in the reserve has heightened tensions with regard to how and to what extent cattle can be absorbed into the rubber tapper's cultural identity and more broadly a sustainable vision of the CMER.

For the CBTM sector, drivers of development have been state policies focused on productive conservation of Acre's expansive areas of natural forest, and the revision of the CMER Management Plan, which has opened a space for CBTM as a livelihood strategy in the reserve. In turn, this has driven demand for CBTM by reserve households seeking new income streams. Projects implemented in the CMER have provided income to participating households, and proponents of CBTM argue that the potential exists to reduce illegal logging and deforestation. Relationships between reserve households and outside agencies implementing CBTM are fraught with mistrust as projects linger in bureaucratic processes, and communication is often poor, with disagreements over rights and control over resources (Cooper \& Kainer, 2018). Critical challenges remain, including the development of local capacity to administer CBTM projects, and large investments required for timber extraction operations. The development of CBTM, like cattle, has also accentuated philosophical differences regarding what constitutes an acceptable extractive 
reserve livelihood, both among households within the CMER and among and across diverse stakeholder groups, both within and outside the reserve.

Now closing in on 2020, and three decades since the establishment of the CMER, new generations of rubber tappers move forward in a dynamic and rapidly changing socioeconomic, cultural and political environment. The rubber tapper united vision of ending conflicts with local ranchers and securing long-term access to land to ply their extractivist trade now must accommodate diverse land-use practices and visions of what constitutes a sustainable livelihood in the CMER. In addition, continued economic inequality among households suggests the need for a vision that recognizes the diversity among households, and focuses on policies that not only create income-earning opportunities but lifts up the households in most dire financial situations.

In his book, Walking the Forest with Chico Mendes, Gomercindo Rodrigues (2007) highlighted that one great challenge that rubber tappers faced in the 1980s in the decade prior to the murder of Chico Mendes was mistrust among rubber tapper households. Many households were highly suspicious of the introduction of Project Rubber Tapper, funded by outside organizations to support in-forest education, establish a strong cooperative, and build the union movement. The rubber tappers did not perceive the activities of Project Rubber Tapper as homegrown, so it failed to build union membership, and the cooperative initially failed. Rodrigues argued that only by going landholding by landholding was it possible to rebuild trust and confidence in the project and its goals (cf. Wallace, 2012).

With CBTM pilot projects underway, cattle herds growing among some reserve households, and NTFP development progressing, although undergoing significant challenges, it seems that rubber tapper leaders, rather than outside organizations, will need to bring CMER community leaders, and subsequently reserve households, together to discuss and debate the opportunities and benefits that each trajectory brings. There needs to be an open discussion regarding real challenges, including the need for highly trained project administrators, better communication between reserve leaders and residents (and among residents), and with outside agencies, and the potential negative impacts of unlimited growth, particularly in the case of cattle. Technologies for more sustainable cattle production in Amazonia exist, but often remain unknown and out of reach of small-scale producers (Gomes et al., 2012c). Programs that support technical assistance and financial support for more sustainable pasture management, such as integrated production systems for crops, cattle and forests, provide incentives for good practices for smallholders, and support communication across small holder cattle households to share experiences across the Amazon could support more sustainable cattle production in the CMER (Gomes et al., 2012c). Hard questions must be asked, such as what might be the limits to growth for cattle ranching and CBTM development for a 30 vision of the CMER? As we noted above, other conservation and development strategies, such as PES, should be explored to better understand their potential complementary role in a diversified rubber tapper household economy. The State of Acre is considered on the forefront in the development of PES programs through its Environmental Services Incentives for Carbon (ISA Carbonne) Program, which extends across both private and public lands (WWF, 2013). Private sector organizations can 
contribute technological advances and support, and develop innovative ideas for product development and commercialization, such as Natex, that can be tailored to the social and spatial reserve realities. There must be a better understanding of the interconnectedness of these three trajectories, and how other household income-earning strategies, such as off-farm labor, transform the reserve landscape.

The discussion of distinct, dynamic and interconnected socio-economic development trajectories of the CMER continues under politicized local and regional debates during three decades of experience on the ground. Cattle raising, which has gained increased economic significance for residents and has direct impact on deforestation patterns in the reserve, for many in the rubber tapper movement represents what they fought against: it is the most controversial theme. Some try to use increasing cattle herds and deforestation in the CMER to question the extractive reserve's utility as a conservation area - and its formal status as a conservation unit - in the Amazon region. However, most criticisms are strongly influenced by politicized ideological visions about Amazon development, and grant insufficient recognition to the wide-ranging benefits of extractive reserves in the region (cf. Barber et al., 2014). Today, extractive reserves encompass approximately 14 million hectares of territories among Amazonian states, resolving land-tenure issues, ending often violent conflicts, improving livelihoods of diverse social groups, and controlling large-scale regional deforestation processes (Gomes et al., 2018).

The extractive reserve social movement across the Amazon has long demanded economic policies to strengthen the regional extractivist economy. In one of his last acts in 2018, the Minister of the
Environment, Sarney Filho, instituted the National Plan for the Strengthening of Extractive Communities - PLANAFE (Presidential Decree No 9.334, April, 2018). The PLANAFE aims to integrate and adapt governmental measures aimed at improving the quality of life and environmental conservation in extractive territories, with four main lines of action: social inclusion, promotion of sustainable production, infrastructure development, and environmental and territorial management. Although this represents an important conquest for reserve residents and advocates, under the current Temer administration, conditions for the extractivist economy of the Amazon have worsened. With the political agenda dominated by the rural landowners' lobby, extractive reserves and other protected areas have been contested to facilitate agribusiness expansion (Schmink et al., 2017).

Although the Forest Government and subsequent ideologically aligned Worker's Party governments have controlled the governorship of Acre for 20 years, the "conceptual architecture" of public policies to increase the value of the standing forest through the diversification of forest extraction is still incipient in meeting both the historical old demands and new aspirations of the populations residing in extractive reserves in Acre. In the CMER, cattle ranching is the product of a lack of harmony between the search for economic improvements by extractive communities, and public policies that commit to and support long-term economic diversification and value-added innovations to strengthen the NTFP sector (Wallace \& Gomes, 2016). It is in this vacuum that cattle ranching (and CBTM) has assumed its place as an economic alternative for income generation (Gomes et al., 2012b). This brings challenges related to the need to strengthen the pacts 
agreed upon 30 years ago between institutions of the social movement and government agencies. For this, the founding values of the CMER need to be reviewed and emphasized, just as new perspectives, values, and visions for the future need to be discussed and deliberated with the strong participation of new generations of reserve residents.

Despite challenges that lie ahead on social, cultural, economic and political fronts, we believe there is political will and hands-on, on-the-ground commitment to bring together reserve leadership, residents and diverse government and non-government agencies to explore how the interlinked trajectories discussed in this article will contribute to the long-term sustainability of the CMER. There is much to celebrate in the 30 years of the CMER experience, as well as in the broader extractive reserve protected area, conceived of by activists of the rubber tapper social movement. Principles of sustainability articulated by Chico Mendes are still reflected across a diversified extractive economy, as well as the millions of hectares of standing forests protected by legal status as conservation units. The legacy of Chico Mendes has cultivated a deeper respect and appreciation for the histories and accomplishments of agroextractivist populations.

\section{References}

Allegretti, M. H. Extractive reserves: an alternative for reconciling development and environmental conservation in Amazonia. In: Anderson, A. B. (Ed.). Alternatives to deforestation: steps toward sustainable use of the Amazonia Rain Forest. New York: Columbia University Press, p.
252-264, 1990.

Allegretti, M. H. Reservas extrativistas: parâmetros para uma política de desenvolvimento sustentável na Amazônia. In: Arndt, R. (Ed.). O Destino da floresta: Reservas Extrativistas e desenvolvimento sustentável na Amazônia. Rio de Janeiro: Dumará, p. 17-47, 1994.

Allegretti, M. H. A construção social de políticas públicas: Chico Mendes e o movimento dos seringueiros. Desenvolvimento e Meio Ambiente, 18, 39-59, 2008. doi: 10.5380/ dma.v18i0.13423

Allegretti, M. H. Políticas, produtos e iniciativas exemplares do extrativismo. In: Carvalho Pires, T.; Carmem B. (Orgs.). Soerguimento tecnológico e econômica do extrativismo na Amazônia. Brasília, DF: Centro de Gestão e Estudos Estratégicos, p. 279-375, 2011. Available at: https://www. cgee.org.br/documents/10195/734063/livro_extrativismo_capa_01092011_7461.pdf/a7dc12a5-3dcd-4dcb-994e-92478 ba 4 a $6 c 7$ ? version $=1.4$

Anderson, A. B.; Ioris, E. M. The logic of extraction: resource management and income generation by extractive producers in the Amazon. In: Padoch, C.; Redford, K. H. (Eds.). Conservation of neotropical forests: working from traditional resource use. New York: Columbia University Press, p. 175-199, 1992.

Bakx, K. Peasant Formation and Capitalist Development: The Case of Acre, South-West Amazonia. Liverpool, Great Britain, Dissertation (Doctorate in Anthropology) - University of Liverpool, 1986.

Barber, C. P.; Cochrane, M. A.; Souza, C. M.; Laurance, W. F. Roads, deforestation, and the mitigating effect of protected areas in the Amazon. Biological Conservation, 177, 203-209, 2014.

Barham, B. L.; Coomes, O. T. Prosperity's promise: the Amazon rubber boom and distorted economic development. Boulder, Colorado: Westview Press, 1996.

Barreto, P.; Souza, J.; Nogueron, R.; Anderson, A.; Salomao, R. Pressão humana na floresta Amazônica Brasileira. Belem, Brasil: WRI-Imazon, 2005.

Browder, J. The limits of extractivism: tropical forest strategies beyond extractive reserves. Bioscience, 42(3), 


\section{4-183,1992.}

Bunker, S. Modes of extraction, unequal Exchange, and the progressive underdevelopment of an extreme periphery: the Brazilian Amazon 1600-1980. American Journal of Sociology, 89(5), 1017-1064, 1984.

Calaça, M. Violência e resistência: O movimento dos seringueiros de Xapuri e a proposta de reserva extrativista. Rio Claro, Tese (Doutorado em Geografia) - Universidade Estadual Paulista, 1993.

Campbell, C. E. Forest, field and factory: changing livelihood strategies in two extractive reserves in the Brazilian Amazon. Gainesville, Florida, Dissertation (Doctorate in Anthropology) - University of Florida, 1996.

Cavalcanti, F. C. de S.; Maciel, R. C. G.; Mangabeira, J. A. de C.; Reydon, B. P. A. Sustentabilidade das reservas extrativistas pela perspectiva da economia ecológica. In: XLVI Congresso de Sociedade Brasileira de Economia, Administração e Sociologia Rural (SOBER). Rio Branco, Acre, July 20 - 23, 2008. Available at: https://ideas.repec. org/p/ags/sbrfsr/113395.html

Clay, J. W. Some general principles and strategies for developing markets in North America and Europe for non-timber forests products: lessons from cultural survival enterprises. In: Nepstad, D.C.; Schwartzman, S. (Eds.). Non-timber products from tropical forests: evaluation of a conservation and development strategy. Advances in Economic Botany, v. 9. Bronx, NY: New York Botanical Garden, p. 101-106, 1992.

CNS - Conselho Nacional Dos Serengueiros. Relatório sócio-econômico e cadastro da Reserva Extrativista Chico Mendes. Rio Branco, Acre, 1992.

Cooper, N. A.; Kainer, K. A. To log or not to log: Local perceptions of timber management and implications for well-being within a sustainable use protected area. Ecology and Society, 23(2), 4, 2018. doi: 10.5751/ES-09995-230204

Da Silva, M. do S. S. Subsídio da borracha e sua relação com os moradores da Resex Chico Mendes: uma análise das contribuições socioeconômicas e ambientais. Manaus, Amazonas, Dissertacao (Mestre em Gestão de Áreas Protegidas na Amazônia) Instituto Nacional de Pesquisas da Amazônia - INPA, 2013.
Dean, W. Brazil and the Struggle for Rubber: A Study in Environmental History, Cambridge, Cambridge University Press, 1987.

Duchelle, A. E.; Guariguata, M. R.; Less, G.; Albornoz, A. M.; Chavez, A.; Melo, T. Evaluating the opportunities and limitations to multiple use of Brazil nuts and timber in Western Amazonia. Forest Ecology and Management, 268, 39-48, 2011. doi: 10.1016/j.foreco.2011.05.023

Duchelle, A. E.; Kainer, K.A.; Wadt, L. H. O. Is certification associated with better forest management and socioeconomic benefits? a comparative analysis of three certification schemes applied to Brazil nuts in Western Amazonia, Society \& Natural Resources: 27(2), 121-139, 2014. doi: 10.1080/08941920.2013.840022

Ehringhaus, C. Post-victory-dilemmas: Land use, development, and social movement in Amazonian Extractive Reserve. New Haven, Tese (Doutorado em Recursos Florestais) - Yale University, 2005.

Faminow, M. D. Cattle, deforestation, and development in the Amazon: an economic, agronomic, and environmental perspective. Wallingford Oxford University Press, 1998.

Fantini, A. C.; Crisóstomo, C. F. Conflicts of interests on the issue of Timber Exploitation within the Chico Mendes Extractive Reserve, Acre, Brazil. Boletim do Museu Paraense Emílio Goeldi. Ciências Humanas, 4(2), 231-246, 2009.

Fearnside, P. M. Extractive reserves in Brazilian Amazonia. Bioscience 39(6), 387-393, 1989.

Gomes, C. V. A. Twenty years after Chico Mendes: Extractive Reserves' expansion, cattle adoption and evolving self-definition among rubber tappers in the Brazilian Amazon. Gainesville, Tese (Doutorado em Geografia) - University of Florida, 2009.

Gomes, C. V. A. Dynamics of land use in an Amazonian extractive reserve: The case of the Chico Mendes Extractive Reserve in Acre, Brazil. Gainesville, Tese (Mestrado em Estudos Latinamericanos) - University of Florida, 2001

Gomes, C. V. A.; Alencar, A. A. C.; Vadjunec, J. M.; Pacheco, L. M. Extractive reserves in the Brazilian Amazon 30 years after Chico Mendes: social movement achievements, territorial expansion and continuing struggles. Desenvolvi- 
mento e Meio Ambiente, forthcoming, 2018.

Gomes, C. V. A.; Vadjunec, J. M.; Perz, S. G. Rubber tapper identities: political-economic dynamics, livelihood shifts, and environmental implications in a changing Amazon. Geoforum, 43(2), 260-271, 2012a. doi: 10.1016/j.geoforum.2011.09.005

Gomes, C. V. A; Perz, S. G.; Vadjunec, J. M. Convergence and contrasts in the adoption of cattle ranching: comparisons of smallholder agriculturalists and forest extractivists in the Amazon. Journal of Latin American Geography, 11(1), 99-120, 2012b.

Gomes, C. V. A.; Ehringhaus, C.; Dutra, C. M.; Pantoja, E.; Toni, F.; Schielein, J.; Hargrave, J.; Carvalheiro, K.; Rocha, L.; Neto, M.; Roper, M.; Zipper, V.; Wirsig, W. Oportunidades de apoio a atividades produtivas sustentáveis na Amazônia: Subsídios para o debate. Brasília-DF: Cooperação Alemã para o Desenvolvimento Sustentável (GIZ); Fundo Amazônia, BNDES, 2012c. Available at: http://www. amazonfund.gov.br/export/sites/default/pt/.galleries/documentos/biblioteca/GIZ_Estudo_Oportunidades_APS.pdf

Hajjar, R.; Kozak, R. A.; El-Lakany, J.; Innes, J. L. Community forests for forest communities: Integrating community-defined goals and practices in the design of forestry initiatives. Land Use Policy, 34, 158-167, 2013. doi: 10.1016/j.landusepol.2013.03.002

Hechenberger, S. Licitação em prestação de serviços em manejo florestal para o Estado: o caso COOPERFLORESTA. Rio Branco, AC, Brazil, UFPR - 2013. [online]: https:// acervodigital.ufpr.br/bitstream/handle/1884/50961/R\%20 -\%20E\%20-\%20SIMONY\%20HECHENBERGER.pdf?sequence $=1 \&$ is Allowed $=\mathrm{y}$

Hoelle, J. Rainforest cowboys: the rise of ranching and cattle culture in western Amazonia. Austin: University of Texas Press. 2015.

Hoelle, J. Convergence on cattle: political economy, social group perceptions, and socioeconomic relationships in Acre, Brazil. Culture, Agriculture, Food. and Environment, 33(2), 2011.

Homma, A. K. O. Extrativismo vegetal na Amazônia: limites e oportunidades. Brasília: EMBRAPA-SPI. 1993.
Humphries, S.; Holmes, T.; de Andrade, D. F. C.; McGrath, D.; Dantas, J. B. Searching for win-win forest outcomes: Learning-by-doing, financial viability, and income growth for a community-based forest management cooperative in the Brazilian Amazon. World Development, 2018. doi: 10.1016/j.worlddev.2018.06.005

IBAMA - Instituto Brasileiro do Meio Ambiente e dos Recurso Naturais Renováveis. Plano de utilizaçao da Reserva Extrativista Chico Mendes, Acre. Projeto para as reservas extrativistas. Brasilia: IBAMA, 1995.

ICMBio - Instituto Chico Mendes de Conservação da Biodiversidade. Instrução Normativa $\mathrm{N}^{\circ} 16$, de 4 de Agosto de 2011. Brasil. Retrieved from http://www.icmbio.gov.br/ portal/images/stories/o-que-somos/in162011.pdf

ICMBio - Instituto Chico Mendes de Conservação da Biodiversidade - \& MMA - Ministério do Meio Ambiente. $O$ que é manejo florestal comunitário - (MFC). Informativo Comunitário: Reserva Extrativista Chico Mendes, 2015 (4), 1-2, 2016.

IFT - Instituto Floresta Tropical. Reflexões sobre a execução do Projeto de Apoio ao Desenvolvimento do Manejo Florestal Comunitário e Familiar em Florestas Públicas da Amazônia Brasileira. Belém, Pará, 2016.

Jaramillo-Giraldo, C.; Soares Filho, B.; Ribeiro, C. M. V.; Gonçalves, R. C. Is it possible to make rubber extraction ecologically and economically viable in the Amazon? The southern Acre and Chico Mendes Reserve case study. Ecological Economics, 134, 186-197, 2017. doi: 10.1016/j. ecolecon.2016.12.035

Kainer, K. A.; Duryea, M. L. Tapping women's knowledge: plant resource use in extractive reserves, Acre, Brazil. Economic Botany, 46(4), 408-425, 1992. doi: 10.1007/ BF02866513

Kainer, K. A.; Schmink, M.; Leite, A. C. P.; Fadell, M. J. da S. Experiments in forest-based development in western Amazonia. Society and Natural Resources, 16(10), 869-886, 2003. doi: 10.1080/716100619

Kauano, É. E.; Silva, J. M. C.; Michalski, F. Illegal use of natural resources in federal protected areas of the Brazilian Amazon. PeerJ, 5, e3902, 2017. doi: 10.7717/peerj.3902 
Leite, A. C. P. Neoextrativismo e desenvolvimento no estado do Acre: O caso do manejo comunitário do óleo de copaíba na reserve extrativista Chico Mendes. Florianópolis, Santa Catarina, Brazil. (Mestrado em Agroecossistemas) - UFSC, 2004.

Lima, A. Em decadência, Natex é "abandonada" por Sebastião Viana e preocupa trabalhadores da fábrica. oaltoacre. com, August 2, 2016. Available at: https://www.oaltoacre. com/em-decadencia-natex-e-abandonada-por-tiao-viana-e-preocupa-trabalhadores-da-fabrica/

Ludewigs, T.; D’Antona, A.D.; Brondizio, E. S.; Hetrick, S. Agrarian structure and land-cover change along the lifespan of three colonization areas in the Brazilian Amazon. World Development, 37(8), 1348-1359, 2009.

Maciel, R. C. G. (Org.). Diagnóstico socioeconômico dos sistemas

básicos de produção familiar rural do estado do Acre (ASPF): período 1996/2006. Rio Branco: Edufac, 2011. Available at: http://www.ufac.br/site/unidades-administrativas/orgaos-complementares/edufac/catalogo-de-publicacoes-1/diagnostico-socioeconomico-dos-sistemas-basicos-de-producao-familiar-rural-do-estado-do-acre-aspf-periodo-1996-2006. Accessed July 30, 2018.

Medeiros, M. da F. e S. T.; Garcia L. O consumo e as estratégias de caça utilizadas pelas populações tradicionais da Reserva Extrativista Chico Mendes. INTERAÇÕES. Revista Internacional de Desenvolvimento Local, 7(12), 121-134, 2005.

Medina, G.; Pokorny, B.; Campbell, B. Community forest management for timber extraction in the Amazon frontier. International Forestry Review, 11(3), 408-420, 2009. doi: 10.1505/ifor.11.3.408

Medina, G.; Pokorny, B. Avaliação financeira do manejo florestal comunitário. Novos Cadernos NAEA, 14(2), 2536, 2011.

Ming, L.; Amaral Junior, A. Aspectos etnobotanicos de plantas medicinas na Reserva Extrativista "Chico Mendes". Florística e Botânica Econômica do Acre, Brasil. The New York Botanical Garden. Universidade Federal do Acre. Available at: https://www.nybg.org/bsci/acre/www1/medicinal. html. Accessed April 2018.
MMA - Ministério do Meio Ambiente. Plano de Manejo: Reserva Extrativista Chico Mendes. Xapuri, AC, Brasil: Ministério do Meio Ambiente, 2006. [online] URL: http:// www.icmbio.gov.br/portal/images/stories/imgs-unidades-coservacao/resex_chico_mendes.pdf

MMA - Ministério do Meio Ambiente. Sistema Nacional de Unidades de Conservação - SNUC, 2000. Disponível em: http://www.mma.gov.br/areas-protegidas/sistema-nacional-de-ucs-snuc. Acesso em: Jan. 2018.

Nepstad, D. C.; Stickler, C. M.; Almeida, O. T.; Globalization of the Amazon soy

and beef industries: opportunities for conservation. Conservation Biology, 20(6), 1595-1603, 2006.

Pacheco, P. Agrarian reform in the Brazilian Amazon: Its Implications for land distribution and deforestation. World Development, 37(8), 1337-1347, 2009.

Pacheco, P.; Poccard-Chapuis. R. The complex evolution of cattle ranching development amid market integration and policy shifts in the Brazilian Amazon. Annals of the Association of American Geographers, 102(6), 1366-90, 2012.

Perz, S. G. The changing social contexts of deforestation in the Brazilian Amazon. Social Sciences Quarterly, 83, 35-52, 2002.

Peters, C. M.; Gentry, A. W.; Mendelsohn, R. O. Valuation of an Amazonian rainforest. Nature, 339(6227), 655-656, 1989. doi: $10.1038 / 339655 \mathrm{a} 0$

Piketty, M.G.; Drigo, I.; Sablayrolles, P.; Araujo, E.; Pena, J. W. P.; Sist, P. Current barriers threatening income generation from community-based forest management in the Brazilian Amazon. In: Katila, P.; Galloway, G.; de Jong, W.; Pacheco, P.; Mery, G. (Eds.). Forests under pressure - local responses to global issues. International Union of Forest Research Organizations, 2015. p. 71-82. Available at: https://www.iufro.org/download/file/27941/6596/ws32 PII_ch03_Brazilian_Amazon_pdf/

Pokorny, B.; Pacheco, P. Money from and for forests: A critical reflection on the feasibility of market approaches for the conservation of Amazonian forests. Journal of Rural Studies, 36, 441-452, 2014. doi: 10.1016/j.jrurstud.2014.09.004 
Rego, J. F. do. Amazonia: do extrativismo ao neoextrativismo. Ciência Hoje, 25(147), 62-65, 1999.

Rocha, E. Potencial ecológico para o manejo de frutos de açaizeiro (Euterpe precatoria Mart.) em áreas extrativistas no Acre, Brasil. ACTA Amazonica, 34(2), 237-250, 2004.

Rodrigues, G. Walking the Forest with Chico Mendes: Struggle for Justice in the Amazon Rainforest. Edited and Translated by Linda Rabben, Austin, TX: University of Texas Press, 2007.

Sabogal, D.; Nascimento, S.; Meneses, L. Community-based forest monitoring: experiences from the Chico Mendes Extractive Reserve. Oxford, England: Global Canopy Programme, 2015. Available at: https://forestcompass.org/ how/resources/community-forest-monitoring-experiences-chico-mendes-extractive-reserve

Salisbury, D. S.; Schmink, M. Cows versus rubber: changing livelihoods among Amazonian extractivists. Geoforum, 38(6), 1233-49, 2007. doi: 10.1016/j.geoforum.2007.03.005

Santos, R. História Econômica da Amazônia (1800-1920). São Paulo: T.A. Queiroz, 1980.

Sassagawa, H. S. Técnicas de sensoriamento remoto e sistema de informações geográficas (SIG) para estudo de ocupação do espaço físico e dos tipos florestais da reserva extrativista Chico Mendes, Estado do Acre. São José dos Campos, Dissertação (Mestrado em Sensoriamento Remoto) - Instituto Nacional de Pesquisas Espaciais-INPE, 1999.

Schmink, M. Amazonian resistance movements and the international alliance. In: Kosinski, L. A. (Ed.). Ecological disorder in Amazonia: social aspects. Rio de Janeiro: UNESCO/ISSC/Educam. p. 149-172, 1992.

Schmink, M.; Wood, C. H. Contested Frontiers in Amazonia. New York: Colombia University Press, 1992.

Schmink, M.; Hoelle, J.; Gomes, C. V. A.; Thaler, G. From contested to "green" frontiers in the Amazon? A long-term analysis of São Félix do Xingu, Brazil. The Journal of Peasant Studies, 1-23, 2017.

Schmink, M.; Duchelle, A; Hoelle; J. d'Oliveira, M. V.; Vadjunec, J.; Wallace. R. Forest citizenship in Acre, Brazil. In: Katila, P.; Galloway, G.; de Jong, W.; Pacheco, P.; Mery, G. (Eds.). Forests under pressure - local responses to global issues. International Union of Forest Research Organizations. p. 31-47. 2014. Available at: https://www. iufro.org/download/file/27939/6596/ws32-PII_ch01_Acre_ Brazil_pdf/

SEMA - Secretaria de Estado de Meio Ambiente. Diagnóstico socioecônomico e cadastro da Reserva Extrativista Chico Mendes: Plano Resex Sustentável. Rio Branco-AC, SEMA, 2010, 77p.

Smeraldi, R.; May, P. O Reino do Gado: Uma Nova Fase na Pecuarização da Amazônia Brasileira. São Paulo: Amigos da Terra-Amazônia Brasileira. 2008

Stone, S. From tapping to cutting trees: participation and agency in two community-based timber management projects in Acre, Brazil. Gainesville, Tese (Doutorado em Antropologia) - University of Florida, 2003.

Stone, S.; Cronkleton, P.; Amaral, P.; Schmink, M. Acompanhamento para o manejo florestal comunitário no Projeto Cachoeira, Acre, Brasil. Centro para a Pesquisa Florestal Internacional - CIFOR, Indonesia, 2007.

UFAC - Universidade Federal do Acre - Centro de Ciências Biológicas e da Natureza, Curso de Engenharia Florestal. Reserva Extrativista Chico Mendes, Xapuri, Manejo Florestal Comunitário: Crescimento e Produção Florestal. Acre, Brasil: UFAC, 2017.

Vadjunec, J. M. Extracting a livelihood: institutional and social dimensions of deforestation in the Chico Mendes Extractive Reserve, Acre, Brazil. Journal of Latin American Geography, 10(1),151-174, 2011. doi: 10.1353/ lag.2011.0007

Vadjunec, J. M.; Gomes, C. V. A.; Ludewigs. T. Land-use/ land-cover change among rubber tappers in the Chico Mendes Extractive Reserve, Acre, Brazil. Journal of Land Use Science, 4(4), 249-274, 2009

Walker, R.; Browder, J.; Arima, E.; Simmons, C.; Pereira, R.; Caldas, M.; Shirota, R.;

de Zen, S. Ranching and the new global range: Amazonia in the 21st century. Geoforum, 40, 732-745, 2009.

Walker, R.; Moran, E.; Anselin, L. Deforestation and cattle ranching in the 
Brazilian Amazon: external capital and household processes. World Development, 28(4), 683-699, 2000.

Wallace, R. Review of the book, Walking the Forest with Chico Mendes: Struggle for Justice in the Amazon Rainforest by Gomercindo Rodrigues. Edited and Translated by Linda Rabben, Austin, TX: University of Texas Press, 2007. Luso-Brazilian Review, 49(1), 259-262, 2012.

Wallace, R. Changes in household livelihood strategies among rubber tapper households in the Chico Mendes Extractive Reserve in Acre, Brazil in southwest Amazonia: 1996 to 2006. Paper presented at the 108th Annual Meeting of the American Anthropological Association. Philadelphia, PA. December 2-6, 2009.

Wallace, R. The effects of wealth and markets on rubber tapper use and knowledge of forest resources in Acre, Brazil. Gainesville, Tese (Doutorado em Antropologia) - University of Florida, 2004.

Wallace, R.; Ferreira, E. L. Usos, extração e potencial de produção de frutos de três espécies de palmeiras nativas na Reserva Extrativista Chico Mendes, Acre: Implicações para a extração comercial. In: Siviero, A.; Ming, L. C.; Silveira, M.; Daly, D.; Wallace, R. (Orgs.). Etnobotânica e botânica econômica do Acre. Rio Branco-AC: EDUFAC, p. 293-303, 2016. Available at: https://issuu.com/edufac/ docs/lebea_ebook_2016.

Wallace, R.; Gomes, C.V.A. O sistema de comércio de produtos florestais não-madeireiros na Reserva Extrativista, Acre: revisitando o passado para pensar no futuro do extrativismo. In: Siviero, A.; Ming, L. C.; Silveira, M.; Daly, D.; Wallace, R. (Orgs.). Etnobotânica e botânica econômica do Acre. Rio Branco-AC: EDUFAC, p. 375-399, 2016. Available at: https://issuu.com/edufac/docs/lebea_ebook_2016

Wallace, R.; Portela da Silva, M. J.; Lopes de Nascimento, F.; Schmink, M. A Feira de Produtos Florestais do Acre: Fortalecendo Espaços para Integração de Comunidades e Mercados, In: Bensunan, N.; Armstrong, G. (Orgs.). $O$ Manejo da Paisagem, e a Paisagem do Manejo. Brasília, Brasil: Instituto Internacional de Educação do Brasil, p. 263-291, 2008.

Weinstein, B. The Amazon Rubber Boom, 1850-1920. Stanford, CA: Stanford University Press, 1983.
WWF - World Wildlife Fund. Environmental service incentives system in the state of Acre, Brazil. World Wildlife Fund Report, 2013. Available at: http://awsassets.panda.org/ downloads/acre_brazil_sisa_report english_10_13.pdf 